\title{
HETEROSIS AND COMBINING ABILITY EFFECTS FOR SOME TRAITS OF PEA (Pisum sativum L.) \\ Hajar Saeed Askander ${ }^{*}$ Kazheen Fakhri Osman ${ }^{* *}$ \\ University of Duhok \\ College of Agriculture \\ * Field crop department * Horticulture department \\ Email:Hajar.askandar@uod.ac
}

\begin{abstract}
This study was carried out at the college of Agriculture field, University of Duhok, during 2013-2014 growing season. It involved half diallel crosses among five genotypes of pea.The seeds of genotypes (parents and F1 hybrids) were grown according to Randomized Complete Block Design with three replications, to estimate general combining ability effects of the parents and specific combining ability effects of hybrids, heterosis as deviation from mid and better parents for the following characters, Days to $50 \%$ flowering, plant-hieght $(\mathrm{cm})$, numbers of branches plant-1, number of pods plant-1, pods weight plant-1 $(\mathrm{g})$, number of seeds plant-1, numbers of seeds pod-1,100 seed weight (g), seed yield plant-1 (g), dry seed yield plant-1 (g), protein percentage and total chlorophyll percentage.The data was statistically analyzed according to Griffing (1956b) method 2 (fixed model). The results indicated that Parent (Petit provencal) showed the best general combination in the desirable direction for no. of pods plant-1, no. of seeds plant-1, no. of seeds pod-1, seed yield plant-1, dry seed yield plant-1 and total chlorophyll. Hybrid (Thomas laxton x Petit provencal) exhibited significant specific combining ability effect in a desirable direction for plant height, no. of branches plant-1, pods weight plant-1, no. of pods plant-1, no. of seeds plant-1, seed yield plant-1 and dry seed yield plant-1. The hybrids (Avola x Petit provencal) and (Thomas laxton $\mathrm{x}$ Petit provencal) gave the best heterosis in desirable direction measured as a deviation of F1 from mid-parents for days to $50 \%$ flowering, pods weight plant-1, no. of pods plant-1, no. of seeds plant-1, no. of seeds pod-1, seed yield plant-1, dry seed yield plant-1, total chlorophyll and also the same hybrids showed a high heterobeltiosis values for (5) characters for each hybrid which include (pods weight plant-1, no.of pods plant-1, no. of seeds plant-1, seed yield plant-1 and dry seed yield plant-1).
\end{abstract}

Keyword: general and specific combining ability, heterosis in pea.

Corresponding auther:

Received:3/4/2018, Accepted:4/10/2018

\section{INTRODUCTION}

Pea (Pisum sativum L.) is one of the annual herbaceous legume crop belongs to family fabaceae (leguminosae), diploid crop having 14 chromosome $(2 n=14, n=7)$ (sato et al. 2010). Pea originated in the Near East and Mediterranean regions.

It is one of the world's oldest crops cultivated as early as 9,000 year ago for human food and animals feed (Pulse Canada, 2010). Pea is one of the four as most important cultivated legume and world's largest legume crop in production after soybean, peanuts and dry beans (Yoshida et al., 2007; Smykal et al., 2012). Pea is 
an economically valuable pulse crop grown around the globe for its high nutritive value, particularly proteins. Its seeds are rich in protein percent (20-25\%), 50\% slowly digestible starch, $50 \%$ soluble sugars by mass and are also a source of fiber (Bastianelli et al., 1998). This crop are beneficial to human health, phytonutrients, vitamins, anti-oxidants and minerals (Pallavi et al., 2013). Pea is used for other soil restorative aim, because the pea crop through the formation of a symbiotic relationship with soil bacteria Rhizobium leguminosarum enhances soil fertility, which has the capability of fixing nitrogen from the atmosphere in to an available form for the plant uptake which can reduces the need to apply synthetic nitrogen fertilizers (McPhee, 2003). Pea genomics have been well-studied ever since the pioneering work of Gregor Mendel in nineteenth century (Samatadze et al., 2008). Hybridization is one of the plant breeding methods and the most successful approach in increasing the productivity in vegetable crops. Selection of superior genotypes genetically is the most important stage from the stand point of hybridization of vegetable crops in order to develop new genotypes which have desirable characters. Selecting of good parents and crosses one of the main important to vegetable breeders for developing high yielding varieties through either heterosis breeding or pedigree breeding (Inamullah et al., 2006).The combining ability analysis is very important and is an active tool in choosing the desirable parents for hybridization programs. The idea of combining ability was enunciated by Sprague and Tatum (1942). Dixit (2003) from a study of combining ability analysis reported that some crosses showed a significant and desirable SCA effects for number of pods plant-1, plant height and pod yield plant- 1 in pea. Nassef and AL-Rawy (2013) observed hight significant GCA and SCA for plant height, number of branches plant-1, number of green pods plant-1, green pods weight plant1 and seeds pod-1, but GCA was not significant for plant height in pea. AlHamdany (2014) reported that GCA was significant for plant height, seed yield, 100 seed weight, and pods weight but not significant for seeds pod-1, while SCA for most characters was significant in pea. Heterosis is genetically a complex phenomenon depending on the equilibrium of the additive, dominance and their interaction. Heterosis point out to the phenomenon that offspring of different varieties of a species or crosses among species which show speed of development, fertility than both parents and greater biomass. The phenomenon has clearly been recognized in one form or another for centuries by various civilization (Chen, 2010). Patil et al. (2011) studied heterosis in pea and they found significant and desirable heterosis in crosses for green pod yield, number of seeds pod-1, plant height, pods plant-1 over better and mid parents. Some researchers in their studies on heterosis as deviation from mid and better parents found positive heterosis for grain yield, green pods plant-1 and negative heterosis for days to $50 \%$ flowering (Dagla et al., 2013; Sharma and Bora, 2013; Esposito et al., 2013). Kosev (2014) conducted a field study on breeding and genetic assessment of some quantitative traits in pea and showed a highest positive values of heterosis for number of seeds pod-1, plant height, and Tawfiq and Abdulla (2014) obtained negative heterosis for number of days to $50 \%$ flowering, when study the genetic analysis of pea.

The main objectives of the present study is to estimate the effects of general combining ability of parents, and specific combining ability of hybrids and to 
determine the heterosis as compared with mid and best parents, by using half diallel crossing programme.

\section{MATERIALS AND METHODS}

This investigation was carried out at the Research farm, College of Agriculture, University of Duhok during 2013-2014 seasons, by using five different cultivars of pea ((1)Avola (2)Thomas laxton (3)Petit provencal (4)Jof and (5)Local cultivar). The cultivars were sown to obtain 10 hybrids through half diallel cross during growing season 2013. In the next season on 20th of November 2014, the F1 hybrids with parents were arranged in Randomized Complete Block Design with three replications in experimental field, each block was consisted of 15 genotypes (5 parents +10 hybrids). Each genotype planted in three rows of $2.5 \mathrm{~m}$ long and $75 \mathrm{~cm}$ between rows ( 1 row for dry seed yield and 2 other rows for vegetative measurement). One seed per hole was sown with spacing $25 \mathrm{~cm}$ between plant to plant in rows. Application of fertilizer was done according to the recommendations, weed control and other cultural practices were performed according to requirements. The data were collected from 6 plants for vegetative measurements except dry seed yield from 3 plants in each experimental unit on the following characters: Days to $50 \%$ flowering of plants, plant height $(\mathrm{cm})$, number of branches plant-1, number of pods plant-1, pods weight plant-1 (g), number of seeds plant-1, number of seeds pod-1,100 seed weight $(\mathrm{g})$, seed yield plant-1 (g), dry seed yield plant-1 (g), protein percentage and total chlorophyll percentage.

Statistical analysis was done for collecting data using Griffing (1956b) method 2, model 1, using the liner model for the analysis which takes the formula of:

$$
\begin{array}{r}
\text { Yijk }=\mu+g i+g j+\text { sij }+ \text { rk +eijk } \quad \mathrm{i}, \mathrm{j}=1,2 \text {-----n } \\
\mathrm{k}=1,2------\mathrm{r}
\end{array}
$$

Where:

Yijk: observed value (ij) of the experimental unit (k).

$\mu$ : population mean.

gi: general combining ability (GCA) effect for the (i) parent.

gj: general combining ability for the (j) parent.

sij: specific combining ability effect (SCA) for the cross involving parent (i) and (j).

rk: replication (block) effect.

eijk: experimental error effect for observation (ij) in block (k).

General and specific combining ability effects estimated as follows:

$\hat{g} i=\frac{1}{r(n+2)}\left[z i \ldots-\frac{z \cdots}{n}\right]$

$\hat{s} i j=\frac{y i j .}{r}-\frac{[z i . .+z j . .]}{r(n+2)}+\frac{2 y \ldots}{r(n-1)(n+2)}$

$\widehat{\boldsymbol{g}} \boldsymbol{i}=$ General combining ability effect for (i) parent.

$\hat{\boldsymbol{s}} \boldsymbol{i} \boldsymbol{j}=$ Specific combining ability effect for hybrid (ij).

$\boldsymbol{y} \boldsymbol{i} \boldsymbol{j} .=\mathrm{F} 1$ overall mean as a result of crossing parent $((\mathrm{i}))$ with parent $((\mathrm{j}))$.

$\boldsymbol{y} \ldots=$ Sum of the overall mean of all parent and F1 hybrids nonreciprocal.

Estimation of Heterosis $(\mathrm{H})$ : 
Heterosis measured as departure of F1 from mid-parents value and best parents (heterobeltiosis) (Richy, 1946).

$\operatorname{Heterosis}(H) \%=\frac{\bar{F} 1-\overline{M . P}}{\overline{M . P}} \times 100 \mathrm{~g}$

Where:

$\bar{F}=$ Mean of hybrid

$M . P=$ Mid-parents

M.P $=\frac{P 1+P 2}{2}$

Heterosis Over better parent (Heterobeltiosis):

$(\mathrm{Hbp})=\frac{F_{1}-b p}{b p} x(100)$.

\section{RESULT AND DISCUSSION}

The analysis of variance Analysis of variance of genotypes, general and specific combining ability effects for studied traits in half diallel crosses present in table (1) showed highly significant means square of genotypes for days to $50 \%$ flowering, plant height, number of branches plant-1, pods plant-1, seeds plant-1, seed yield plant-1, dry seed yield plant-1, total chlorophyll and significant for pods weight plant-1, seeds pod-1 and 100 seed weight except protein percent was the only traits that didn't showed any significant differences. The general combining ability(GCA) mean square was highly significant for trait days to $50 \%$ flowering, plant height, pods plant-1, seeds plant-1, 100 seed weight, dry seed yield plant-1, total chlorophyll and significant for seeds pod-1 and seed yield plant-1, whereas did not significant for number of branches plant-1, pods weight plant-1 and protein percent. Similar findings were reported by Mitu et al. (2004); Borah (2009). The mean square for specific combining ability (SCA) variance was highly significant and significant for days to $50 \%$ flowering, plant height, number of branches plant-1, pods plant-1, seeds plant-1, seed yield plant-1, dry seed yield plant-1, total chlorophyll, pods weight plant-1 and not significant level for seeds pod-1, 100 seeds weight and protein percent. These results were in agreement with Bisht and Singh, (2011); Dagla et al. (2013).

General combining ability effects.

Table (2) showed the estimation of general combining ability (GCA) effects of parents for studied traits. The highest significant positive GCA effect for days to $50 \%$ flowering was (5.54) for parent (1), while the parent (2) exhibited the highest negative value of GCA with (-9.74). The maximum positive GCA effect for plant height was exhibited by parent (1) (13.76), while the maximum negative GCA effects was noticed for parent (3) (-10.71). For number of branches plant-1, parent (2) showed the highest positive value (0.26) of GCA effects and parent (1) recorded the maximum negative GCA effect value (-0.42). The maximum value for pods weight was showed by parent (3) (7.89), while the maximum negative GCA effect value was recorded by parent (1) (-7.99). The largest positive estimated effect of GCA for pods plant-1 recorded by parent (3) (4.64), whereas the maximum negative GCA effect (-4.15) was noticed for parent (5). For the traits no. of seeds plant-1, no. seeds pod-1, seed yield plant-1, dry seed yield plant-1 and total chlorophyll parent (3) showed the highest positive GCA value (25.50), (0.26), (7.43). (2.60) and (5.20) 
respectively, and the maximum negative value for no. of seeds plant- 1 was observed by parent (1) (-16.33), for no. of seedspod-1 by parent (2) (-0.18), for seed yield plant-1by parent (1) (-4.91), for dry seed yield plant-1 parent (4) (-3.33) and for total chlorophyll by parent (1) (-7.09). For 100 seed weight parents (4) and (5) recorded the maximum positive GCA effect (2.73) and (2.02) respectively, while the maximum negative value noticed by parent (2) $(-4.34)$. For protein percent parent (4) had significant positive GCA effect $(0.52 \%)$, and the maximum negative value observed by parent (2) with (-0.58). The result appeared that the parent (3) gave desirable general combining ability for (6) characters including no. of pods plant-1, no. of seeds plant-1, no. of seeds pod-1, seed yield plant-1, dry seed yield plant-1 and total chlorophyll, followed by parent (2) for (4) characters, days to 50\% flowering, plant height, no. of pods plant-1 and dry seed yield plant-1. These results are in agreement with other researchers (Gritton, 1975; Srivastava et al., 1986; Ceyhan and Avci, 2005; Al-Hamdany, 2014).

Specific combining ability effects.

Estimation of specific combining ability (SCA) effects of hybrids for studied traits were presented in table (3). The hybrid (1x2) recorded highest SCA effect value (11.33) for days to $50 \%$ flowering, and the highest negative SCA effect value (-9.95) was recorded by hybrid $(2 \times 4)$. The maximum positive SCA effect for plant height was scored by hybrid $(1 \mathrm{x} 4)$ with (17.56), whereas the maximum negative value of SCA effect recorded by the hybrid (4x5) (-13.96). For the traits number of branches plant-1, pods weight plant-1, no. of pods plant-1 and no. of seeds plant-1, the hybrid (2x3) showed the highest positive SCA effect value (4.29), (39.88), (23.80) and (97.34), respectively, while the highest negative SCA effects for number of branches was recorded by hybrid $(2 \times 5)$ with $(-2.55)$ and hybrid $(3 \times 5)$ had the negative value for pods weight, no. of pods plant- 1 , no. of seeds plant-1 (30.94), (-15.81) and (-59.85), respectively. The highest positive value of SCA effect noticed by hybrid $(1 \times 4)(0.32)$ and the highest negative value in hybrid $(1 \times 5)(-$ $0.42)$ for no. of seeds pod-1. The hybrid $(2 \times 3)$ gave the maximum positive SCA effect value (21.69) for seed yield followed by hybrid (1x3) (17.77), while the maximum negative value was $(-17.29)$ exhibited by hybrid $(3 \times 5)$. For 100 seed weight, the highest positive SCA effect was recorded by hybrid (3x4) (3.13), while highest negative SCAeffect was recorded by hybrid $(2 \times 4) \quad(-6.12)$, For dry seed yield plant -1 the hybrid $(2 \times 3)$ recorded highest positive SCA effect value (15.26), while highest negative SCA effect was observed in hybrid (2x5) (-9.40). For protein percent the hybrid $(2 \times 5)$ gave highest positive SCA effect value (1.71), and the hybrid (2x3) gave highest negative SCA effect (-3.01). For total chlorophyll, the maximum positive value of SCA effect observed in hybrid (1x3) (9.95) while the maximum negative value $(-5.70)$ recorded by hybrid $(1 \times 2)$. From the obtained results, it was concluded that the hybrid (2x3) were specialized by a significant and positive desirable SCA effect for (7) characters including plant height, no. of branches plant-1, pods weight plant-1, no. of pods plant-1, seed yield plant-1 and dry seed yield plant-1, followed by hybrid (1x3) for (6) characters gave significant desirable SCA effect including days to 50\% flowering, pods weight plant-1, no. of pods plant -1 , no. of seeds plant-1, seed yield plant-1 and total chlorophyll. The significant desirable SCA for hybrids reflected non-additive type of gene action. 
The parents that gave a significant desirable GCA effect indicates that the contribution of this parent increase the important of characters in their hybrids. The hybrids that have highest positive SCA effects means the ability of this parent in transferring this character to most of its hybrids (Sharma etal., 2014). Whereas, the hybrid (1x3) participated parent (1) this parent did not show a significant GCA effect. This result similar with found by Bhardwaj and Kohli (1998), when they reported that the hybrids showing high SCA effect usually didn't involve parents having high GCA, may involve high x low general combining ability.Could be

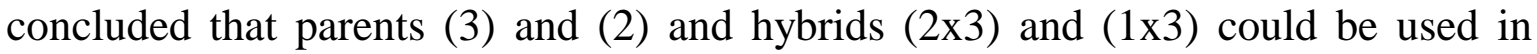
breeding programs to get better hybrid combination for pea cultivars to develop high yielding in pea. These results are in agreement with those of by Kumar and Bal(1995); Sharma (1999); Dixit (2003).

Heterosis.

Table (4) showed the estimation of heterosis as deviation from mid-parents for the studied traits. Hybrid (1x2) had the highest positive heterosis value (11.5) for days to $50 \%$ flowering and hybrid $(2 \times 5)$ had showed highest negative value $(-12.83)$, For plant height the maximum positive heterosis value was (24.93) for hybrid $(1 \times 4)$, while the maximum negative value was $(-3.54)$ for the hybrid $(4 \times 5)$. The hybrid (2x3) recorded significant positive heterosis value (5.47) for no. of branches plant1 whereas hybrid $(2 \times 5)$ gave the maximum negative value of heterosis $(-1.58)$. For pods weight plant-1 the maximum positive heterosis value for hybrid was recorded by hybrids (2x3) and (1x3) with (54.41) and (43.73) respectively, and the maximum negative value recorded for the hybrid (1x2) (-23.73). Significant positive heterosis for no. of pods plant-1 observed in hybrid (2x3) (34.16), while the hybrid $(1 \times 2)$ recorded highest negative value of heterosis with $(-9.69)$, for no. of seeds plant-1 the hybrid (2x3) showed the maximum positive value of heterosis (146.73), while the maximum negative heterosis value (-31.41) recorded by hybrid (1x2). The hybrid $(3 \times 5)$ for no. of seeds pod-1recorded the highest positive heterosis value $(0.72)$, while the hybrid $(4 \times 5)$ showed the maximum negative value with $(-0.32)$. The maximum positive heterosis value for seed yield plant-1 recorded by hybrid (2x3) followed by hybrid (1x3) (32.46), (27.79), respectively and the maximum negative value $(-10.21)$ for heterosis noticed in hybrid $(1 \times 2)$. The hybrid $(3 \times 4)$ recorded maximum positive heterosis value for 100 seed weight with (1.49), while the maximum negative value recorded by $(2 \times 4)(-9.91)$, for dry seed yield plant -1 , the highest positive heterosis value $(21.82)$ by hybrid $(2 \times 3)$ while the highest negative heterosis value recorded by hybrid $(2 \times 5)(-1.58)$. The maximum positive value for heterosis of protein percent $(1.22)$ by hybrid $(4 \times 5)$, while the highest negative value produced by the cross $(2 \times 3)(-4.07)$. The hybrid $(1 \times 3)$ gave the highest value of heterosis (11.01) for total chlorophyll, while the hybrid (1x2) gave the highest negative value of heterosis $(-9.32)$ for this trait. These results agreed with those found by these researcher these researcher (Lejeune-Henaut et al., 1992; Sarawat et al., 1994; Cyhan et al. 2008; Patil et al., 2011; Rai and Mishra, 2013; Tawfiq and Abdulla 2014). The results of study revealed that the hybrid (1x3) showed a significant heterosis over mid parents in desirable direction for (8) characters followed by hybrid $(2 \times 3)$ for $(7)$ characters as compared with other hybrids. 
Heterobeltiosis.

Estimation of heterobeltiosis (heterosis as deviation from better parents) for studied traits were given in table (5). For days to $50 \%$ flowering, the maximum positive heterobeltiosis value (24) was observed by hybrid (1x2), while the maximum negative value was observed by $(2 \times 5)$ and $(2 \times 4)$ with $(-2.33)$ and $(-2.00)$, respectively. The hybrid $(1 \times 4)$ recorded the highest positive heterobeltiosis value (7.99) for plant height, whereas the highest negative value was recorded by hybrid (1x3) (-23.79). The maximum positive heterobeltiosis value for number of branches plant-1 recorded by hybrid (1x5) (1.16), and the hybrid (2x5) recorded the maximum negative value (-1.61). For pods weight plant-1, no. of pods plant-1, no. of seeds plant-1, seed yield plant-1 and dry seed yield plant-1, the hybrid $(2 \times 3)$ showed the maximum positive heterobeltiosis values (47.82), (29.83), (138.59), (31.86) and (21.19) respectively, while the hybrid (1x2) recorded the maximum negative values with $(-30.49),(-14.00),(-45.86)$ and $(-13.21)$ for the same traits respectively except dry seed yield plant-1 was recorded by hybrid $(2 \times 5)$ with $(-$ 3.31). For no. of seedspod-1 the hybrid $(3 \times 5)$ gave the highest positive heterobeltiosis value with $(0.70)$, while the maximum negative value recorded by hybrid (4x5) (-0.55). For 100 seeds weight, hybrid $(3 \times 4)$ recorded the highest heterobeltiosis value $(-1.50)$, while the minimum negative value $(-14.98)$ for hybrid $(2 \times 4)$. Also, for protein percent the hybrid $(1 \times 2)$ showed the maximum positive value of heterobeltiosis (0.93), while the maximum negative value $(-5.12)$ observed by hybrid $(2 \times 3)$. For total chlorophyll the highest positive heterobeltiosis value recorded by hybrid (3x5) (3.50), while the maximum negative value recorded by hybrid (1x2) (-15.69). These results were in agreement with those found by Dagla et al., (2013); Esposito et al., 2013). Depending on the pervious results, it showed that the hybrids (1x3) and (2x3) were exhibited the highest heterobeltiosis for pods weight plant-1, no. of pods plant-1, no. of seeds plant-1, seed yield plant-1 and dry seed yield plant-1. 
Mesopotamia J. of Agric.

Vol. (46) No. (4) 2018
ISSN: $2224-9796$ (Online)

ISSN: 1815 - $316 \mathrm{X}$ (Print)

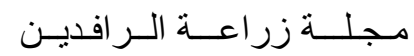

المجلد (46) العدد (4) 2018

Table (1) Analysis of variance (mean squares values) of genotypes, general and specific combining ability effects for studied traits in half diallel crosses.

\begin{tabular}{|c|c|c|c|c|c|c|c|c|c|c|c|c|c|}
\hline \multicolumn{14}{|c|}{ Mean square } \\
\hline $\begin{array}{l}\text { Source of } \\
\text { variation }\end{array}$ & $\begin{array}{c}\text { Charac } \\
\text { t-ers } \\
\text { D.f }\end{array}$ & $\begin{array}{l}\text { Days to } \\
50 \% \\
\text { flowerin } \\
\mathrm{g}\end{array}$ & $\begin{array}{l}\text { Plant } \\
\text { height } \\
(\mathrm{cm})\end{array}$ & $\begin{array}{l}\text { Numbe } \\
\text { r of } \\
\text { branch } \\
\text { es } \\
\text { plant-1 }\end{array}$ & $\begin{array}{l}\text { Pods } \\
\text { weight } \\
\text { plant-1 } \\
\text { (g) }\end{array}$ & $\begin{array}{l}\text { Number } \\
\text { of Pods } \\
\text { plant-1 }\end{array}$ & $\begin{array}{c}\text { Number } \\
\text { of Seeds } \\
\text { plant-1 }\end{array}$ & $\begin{array}{l}\text { Numbe } \\
\text { r of } \\
\text { Seeds } \\
\text { pod-1 }\end{array}$ & $\begin{array}{c}\text { Seed } \\
\text { yield } \\
\text { plant- } \\
1(\mathrm{~g})\end{array}$ & $\begin{array}{c}100 \text { seed } \\
\text { weight } \\
(\mathrm{g})\end{array}$ & $\begin{array}{c}\text { Dry } \\
\text { Seed } \\
\text { yield } \\
\text { plant- } \\
1(\mathrm{~g})\end{array}$ & $\begin{array}{c}\text { Protein } \\
\%\end{array}$ & $\begin{array}{c}\text { Total } \\
\text { Chlorophyl } \\
1\end{array}$ \\
\hline $\begin{array}{c}\text { Replicati } \\
\text { on }\end{array}$ & 2 & 0.266 & 205.66 & 3.20 & 1302.01 & 53.83 & 790.57 & 0.06 & 13.31 & 28.80 & 32.51 & 3.46 & $99.26^{*}$ \\
\hline $\begin{array}{c}\text { Genotype } \\
\text { S }\end{array}$ & 14 & $\begin{array}{c}309.99 * \\
*\end{array}$ & $777.84 * *$ & $6.84 * *$ & $\begin{array}{c}1176.62 \\
*\end{array}$ & $\begin{array}{c}347.90 * \\
*\end{array}$ & $\begin{array}{c}6481.04 * \\
*\end{array}$ & $0.42 *$ & $\begin{array}{c}437.42 * \\
*\end{array}$ & $78.00^{*}$ & $\begin{array}{c}127.92^{*} \\
*\end{array}$ & 6.70 & $182.65 * *$ \\
\hline GCA & 4 & $\begin{array}{c}693.10^{*} \\
*\end{array}$ & $\begin{array}{c}2165.19 * \\
*\end{array}$ & 1.72 & 773.45 & $\begin{array}{c}355.03 * \\
*\end{array}$ & $\begin{array}{c}6646.19 * \\
*\end{array}$ & $0.80 *$ & $454.83 *$ & $\begin{array}{c}160.52 * \\
*\end{array}$ & $\begin{array}{c}143.84 * \\
*\end{array}$ & 5.37 & $450.36 * *$ \\
\hline SCA & 10 & $\begin{array}{c}156.74 * \\
*\end{array}$ & $222.94 * *$ & $8.90 * *$ & $\begin{array}{c}1337.89 \\
*\end{array}$ & $\begin{array}{c}345.04 * \\
*\end{array}$ & $\begin{array}{c}6414.98 * \\
*\end{array}$ & 0.26 & $\begin{array}{c}430.45^{*} \\
*\end{array}$ & 44.99 & $\begin{array}{c}121.55^{*} \\
*\end{array}$ & 7.24 & $75.57 * *$ \\
\hline \multicolumn{2}{|c|}{ GCA/SCA } & 0.63 & 1.66 & 0.002 & 0.05 & 0.14 & 0.14 & 0.70 & 0.15 & 0.97 & 0.17 & 0.06 & 1.02 \\
\hline Error & 28 & 0.31 & 41.14 & 1.57 & 419.85 & 44.84 & 540.48 & 0.13 & 84.27 & 25.09 & 12.10 & 4.01 & 15.16 \\
\hline
\end{tabular}

*and ** significant difference at probability level of 0.05 and 0.01 respectively. 
Mesopotamia J. of Agric.

Vol. (46) No. (4) 2018
ISSN: 2224 - 9796 (Online)

ISSN: 1815 - $316 \mathrm{X}$ (Print)
مجلــــة زر اعــة الــر افديـن

المجلد (46) العدد (4) 2018

Table (2) Estimation of general combining ability effects of parents for studied traits.

\begin{tabular}{|c|c|c|c|c|c|c|c|c|c|c|c|c|}
\hline parents & $\begin{array}{c}\text { Days to } \\
50 \% \\
\text { flowering }\end{array}$ & $\begin{array}{l}\text { Plant } \\
\text { height } \\
(\mathrm{cm})\end{array}$ & $\begin{array}{l}\text { Numbe } \\
\text { r of } \\
\text { branch } \\
\text { esplant } \\
-1\end{array}$ & $\begin{array}{c}\text { Pods } \\
\text { weight } \\
\text { plant-1 } \\
(\mathrm{g})\end{array}$ & $\begin{array}{l}\text { Number } \\
\text { of Pods } \\
\text { plant-1 }\end{array}$ & $\begin{array}{l}\text { Number } \\
\text { of Seeds } \\
\text { plant-1 }\end{array}$ & $\begin{array}{l}\text { Number } \\
\text { of seeds } \\
\text { pod-1 }\end{array}$ & $\begin{array}{l}\text { seed } \\
\text { yield } \\
\text { plant-1 } \\
(\mathrm{g})\end{array}$ & $\begin{array}{c}100 \text { seed } \\
\text { weight } \\
(\mathrm{g})\end{array}$ & $\begin{array}{l}\text { dry Seed } \\
\text { yield } \\
\text { plant-1 } \\
\text { (g) }\end{array}$ & $\begin{array}{c}\text { Protein } \\
\%\end{array}$ & $\begin{array}{c}\text { Total } \\
\text { chlorophy } \\
11\end{array}$ \\
\hline $\mathrm{P} 1$ & $5.54 * *$ & $13.76 * *$ & -0.42 & -7.99 & $-3.65^{*}$ & $-16.33 *$ & -0.08 & -4.91 & -0.29 & $-2.17 *$ & -0.48 & $-7.09 * *$ \\
\hline $\mathrm{P} 2$ & $-9.74 * *$ & $7.20 * *$ & 0.26 & -0.16 & $3.86 *$ & 10.96 & -0.18 & -1.14 & $-4.34 * *$ & $1.98 *$ & -0.58 & -1.54 \\
\hline P3 & $1.63 * *$ & $-10.71 * *$ & 0.25 & 7.89 & $4.64 *$ & $25.50 * *$ & $0.26 * *$ & $7.43 * *$ & -0.12 & $2.60 * *$ & 0.16 & $5.20 * *$ \\
\hline $\mathrm{P} 4$ & $0.82 * *$ & $-3.80 *$ & 0.01 & 3.37 & -0.70 & -6.52 & -0.13 & 0.87 & $2.73 *$ & $-3.33 * *$ & 0.52 & 1.55 \\
\hline P5 & $1.73 * *$ & $-6.44 * *$ & -0.10 & -3.11 & $-4.15^{*}$ & $-13.62 *$ & 0.14 & -2.24 & 2.02 & 0.91 & 0.37 & 1.87 \\
\hline
\end{tabular}

*and $* *$ significant difference at level 0.05 and 0.01 respectively. 
Mesopotamia J. of Agric.

Vol. (46) No. (4) 2018
ISSN: 2224 - 9796 (Online)

ISSN: 1815 - $316 \mathrm{X}$ (Print)
مجلــــة زر اعــة الــر افديـن

المجلد (46) العدد (4) 2018

Table (3) Estimation of specific combining ability effects of hybrids for studied traits.

\begin{tabular}{|c|c|c|c|c|c|c|c|c|c|c|c|c|}
\hline parents & $\begin{array}{l}\text { Days to } \\
50 \% \\
\text { flowerin } \\
\mathrm{g}\end{array}$ & $\begin{array}{l}\text { Plant } \\
\text { height } \\
(\mathrm{cm})\end{array}$ & $\begin{array}{l}\text { Number } \\
\text { of } \\
\text { branche } \\
\text { splant-1 }\end{array}$ & $\begin{array}{c}\text { Pods } \\
\text { weight } \\
\text { plant- } \\
1(\mathrm{~g})\end{array}$ & $\begin{array}{l}\text { Number } \\
\text { of Pods } \\
\text { plant-1 }\end{array}$ & $\begin{array}{l}\text { Number } \\
\text { of Seeds } \\
\text { Plant-1 }\end{array}$ & $\begin{array}{c}\text { Numbe } \\
\text { r of } \\
\text { Seeds } \\
\text { pod-1 }\end{array}$ & $\begin{array}{l}\text { Seed } \\
\text { yield } \\
\text { plant-1 } \\
(\mathrm{g})\end{array}$ & $\begin{array}{c}100 \text { seed } \\
\text { weight } \\
(\mathrm{g})\end{array}$ & $\begin{array}{l}\text { Dry seed } \\
\text { yield } \\
\text { plant-1 } \\
\text { (g) }\end{array}$ & $\begin{array}{c}\text { Protein } \\
\%\end{array}$ & $\begin{array}{c}\text { Total } \\
\text { Chlorophyl } \\
1\end{array}$ \\
\hline P1XP2 & $11.33 * *$ & 0.06 & -0.51 & -22.54 & $-11.72^{*}$ & $-45.22 * *$ & 0.06 & -11.03 & 2.00 & -4.03 & 1.58 & $-5.70^{*}$ \\
\hline P1XP3 & $-7.38 * *$ & -7.31 & -0.34 & $30.27 *$ & $11.15^{*}$ & $53.66 * *$ & 0.26 & $17.77 * *$ & -0.02 & 3.14 & 0.50 & $9.95 * *$ \\
\hline P1XP4 & $1.09 * *$ & $17.56^{* *}$ & -0.66 & -9.89 & -3.09 & -7.15 & 0.32 & -4.14 & -1.66 & 1.79 & -1.75 & -4.93 \\
\hline P1XP5 & $-2.09 * *$ & -2.30 & 1.51 & -0.10 & 2.47 & -0.32 & -0.42 & -2.54 & -1.16 & 0.88 & -0.78 & -2.12 \\
\hline P2XP3 & $4.57 * *$ & $9.07 *$ & $4.29 * *$ & $39.88 * *$ & $23.80 * *$ & $97.34 * *$ & -0.08 & $21.69 * *$ & -3.36 & $15.26 * *$ & $-3.01 *$ & -2.17 \\
\hline P2XP4 & $-9.95 * *$ & 0.48 & -0.57 & -2.54 & 2.05 & 12.26 & 0.16 & -2.40 & -6.12 & 3.48 & -1.04 & -0.36 \\
\hline P2XP5 & $-8.57 * *$ & -2.03 & $-2.55 * *$ & -14.91 & -8.90 & $-37.72 *$ & 0.003 & -6.67 & 1.67 & $-9.40 * *$ & 1.71 & 3.80 \\
\hline P3XP4 & $5.00 * *$ & 2.64 & -0.17 & -10.02 & -3.67 & -19.04 & -0.20 & -2.23 & 3.13 & -1.87 & -0.29 & 0.09 \\
\hline P3XP5 & 0.61 & -3.58 & $-2.08 *$ & -30.94 & $-15.81 * *$ & $-59.85 * *$ & 0.29 & $-17.29 * *$ & -1.23 & $-8.71 * *$ & 1.44 & -2.97 \\
\hline P4XP5 & $4.71 * *$ & $-13.96 * *$ & 1.07 & 14.14 & 2.03 & 2.37 & -0.31 & 2.92 & 2.88 & -0.82 & 2.22 & 4.17 \\
\hline
\end{tabular}

*and **significant difference at level 0.05 and 0.01 respectively 
Mesopotamia J. of Agric.

Vol. (46) No. (4) 2018
ISSN: 2224 - 9796 (Online)

ISSN: 1815 - $316 \mathrm{X}$ (Print)
مجلــــة زر اعــة الــر افديـن

المجلد (46) العدد (4) 2018

Table (4) Estimation of heterosis over to mid parents for studied traits.

\begin{tabular}{|c|c|c|c|c|c|c|c|c|c|c|c|c|}
\hline Hybrids & $\begin{array}{c}\text { Days to } \\
50 \% \\
\text { flowering }\end{array}$ & $\begin{array}{l}\text { Plant } \\
\text { height } \\
(\mathrm{cm})\end{array}$ & $\begin{array}{c}\text { Number } \\
\text { of } \\
\text { branch } \\
\text { Plant-1 }\end{array}$ & $\begin{array}{l}\text { Pods } \\
\text { weight } \\
\text { plant-1 } \\
\text { (g) }\end{array}$ & $\begin{array}{l}\text { Number } \\
\text { of Pods } \\
\text { plant-1 }\end{array}$ & $\begin{array}{c}\text { Number } \\
\text { of Seeds } \\
\text { plant-1 }\end{array}$ & $\begin{array}{c}\text { Number } \\
\text { of } \\
\text { Seeds } \\
\text { pod-1 }\end{array}$ & $\begin{array}{l}\text { Seed } \\
\text { yield } \\
\text { plant-1 } \\
(\mathrm{g})\end{array}$ & $\begin{array}{c}100 \\
\text { seed } \\
\text { weight } \\
(\mathrm{g})\end{array}$ & $\begin{array}{c}\text { Dry } \\
\text { seed } \\
\text { yield } \\
\text { plant-1 } \\
(\mathrm{g}) \\
\end{array}$ & $\begin{array}{c}\text { Protein } \\
\%\end{array}$ & $\begin{array}{c}\text { Total } \\
\text { chlorophyll }\end{array}$ \\
\hline $1 \times 2$ & $11.50 * *$ & $7.86^{*}$ & -0.19 & -23.73 & $-9.69 *$ & $-31.41 *$ & 0.24 & -10.21 & -1.31 & -0.49 & 0.98 & $-9.32 * *$ \\
\hline $1 \times 3$ & $-4.50 * *$ & -2.90 & 0.50 & $43.73 * *$ & $18.30 * *$ & $90.20 * *$ & $0.51 *$ & $27.77 * *$ & -1.19 & $7.94 * *$ & -0.39 & $11.01 * *$ \\
\hline $1 \times 4$ & $3.00 * *$ & $24.93 * *$ & -0.83 & -15.18 & -5.02 & -12.46 & 0.42 & -7.05 & -2.98 & 3.97 & -2.40 & $-6.85 * *$ \\
\hline $1 \times 5$ & $2.00 * *$ & $10.01 *$ & 1.50 & -6.83 & -0.13 & -0.73 & -0.05 & -4.42 & -4.37 & 3.42 & -1.15 & $-6.45^{*}$ \\
\hline $2 \times 3$ & $4.66 * *$ & $13.28 * *$ & $5.47 * *$ & $54.41 * *$ & $34.16 * *$ & $146.73 * *$ & 0.11 & $32.46 * *$ & $-7.01 *$ & $21.82 * *$ & $-4.07 * *$ & -1.94 \\
\hline $2 \times 4$ & $-10.83 * *$ & 7.65 & -0.41 & -6.76 & 3.33 & 19.81 & 0.21 & -4.54 & $-9.91 * *$ & $7.42 * *$ & -1.85 & -3.10 \\
\hline $2 \times 5$ & $-12.83 * *$ & $9.67 *$ & $-1.58 *$ & -18.43 & -1.88 & 0.43 & 0.25 & -6.26 & $-8.96 * *$ & -1.58 & 0.87 & -2.97 \\
\hline $3 \times 4$ & $6.83 * *$ & 6.42 & 0.50 & 0.41 & 2.72 & 11.22 & -0.08 & 4.81 & 1.49 & 3.32 & -1.40 & 2.03 \\
\hline $3 \times 5$ & $4.50 * *$ & -2.04 & 0.44 & 9.49 & 6.55 & $46.47 * *$ & $0.72 * *$ & 10.67 & -5.40 & 2.87 & -0.30 & 4.26 \\
\hline $4 \times 5$ & $5.66 * *$ & -3.54 & 0.55 & -1.66 & -2.83 & -16.82 & -0.32 & -7.84 & -1.72 & 2.91 & 1.22 & 2.49 \\
\hline
\end{tabular}

*and ${ }^{* *}$ significant difference at level 0.05 and 0.01 respectively. 
Mesopotamia J. of Agric.

Vol. (46) No. (4) 2018
ISSN: 2224 - 9796 (Online)

ISSN: 1815 - $316 \mathrm{X}$ (Print)
مجلــــة زر اعــة الــر افديـن

المجلد (46) العدد (4) 2018

Table (5) Estimation of heterobeltiosis (heterosis over better parents) for studied traits.

\begin{tabular}{|c|c|c|c|c|c|c|c|c|c|c|c|c|}
\hline Hybrids & $\begin{array}{c}\text { Days to } \\
50 \% \\
\text { flowering }\end{array}$ & $\begin{array}{c}\text { Plant } \\
\text { height } \\
(\mathrm{cm})\end{array}$ & $\begin{array}{c}\text { Number } \\
\text { of } \\
\text { branches } \\
\text { Plant-1 }\end{array}$ & $\begin{array}{c}\text { Pods } \\
\text { weight } \\
\text { plant-1 } \\
\text { (g) }\end{array}$ & $\begin{array}{l}\text { Number } \\
\text { of Pods } \\
\text { plant-1 }\end{array}$ & $\begin{array}{l}\text { Number } \\
\text { of Seeds } \\
\text { plant-1 }\end{array}$ & $\begin{array}{l}\text { Number } \\
\text { of } \\
\text { Seeds } \\
\text { pod-1 }\end{array}$ & $\begin{array}{c}\text { Seed } \\
\text { yield } \\
(\mathrm{g})\end{array}$ & $\begin{array}{c}100 \\
\text { seed } \\
\text { weight } \\
(\mathrm{g})\end{array}$ & $\begin{array}{l}\text { Dry } \\
\text { Seed } \\
\text { yield } \\
(\mathrm{g})\end{array}$ & $\begin{array}{c}\text { Protein } \\
\%\end{array}$ & $\begin{array}{c}\text { Total } \\
\text { Chlorophyll }\end{array}$ \\
\hline $1 \times 2$ & $24.00 * *$ & 1.50 & -0.55 & $-30.49 *$ & $-14.00 * *$ & $-45.86^{*}$ & 0.18 & $-13.21 *$ & -2.89 & -2.88 & 0.93 & $-15.69 * *$ \\
\hline $1 \times 3$ & -0.66 & $-23.79 * *$ & 0.33 & $43.57 * *$ & $18.27 * *$ & $83.93 * *$ & 0.17 & $25.37 * *$ & -1.68 & $6.18 *$ & -1.50 & 2.56 \\
\hline $1 \times 4$ & $6.66 * *$ & 7.99 & -1.44 & $-29.57 *$ & -8.72 & -28.53 & 0.33 & $\begin{array}{c}- \\
15.81 * *\end{array}$ & -6.47 & 2.41 & $-3.62 *$ & $-14.62 * *$ \\
\hline $1 \times 5$ & $4.00 * *$ & -6.51 & 1.16 & -13.91 & -0.38 & -5.76 & -0.36 & -9.08 & $-8.21 *$ & -0.69 & -1.5 & $-14.14 * *$ \\
\hline $2 \times 3$ & $13.33 * *$ & -1.25 & 0.30 & $47.82 * *$ & $29.83 * *$ & $138.54 * *$ & -0.27 & $31.86^{* *}$ & $-9.07 *$ & $21.19 * *$ & $-5.12 * *$ & -4.01 \\
\hline $2 \times 4$ & $-2.00 * *$ & -2.92 & -0.66 & -14.40 & 2.72 & 18.19 & 0.08 & -10.29 & $\begin{array}{c}- \\
14.98^{* *}\end{array}$ & 3.47 & $-3.02 *$ & -4.50 \\
\hline $2 \times 5$ & $-2.33 * *$ & -0.49 & -1.61 & -18.76 & -6.44 & -8.98 & -0.11 & -7.92 & $\begin{array}{c}- \\
14.37 * * \\
\end{array}$ & -3.31 & 0.58 & -4.29 \\
\hline $3 \times 4$ & $7.00 * *$ & 2.47 & -0.27 & -13.81 & -1.00 & 1.41 & -0.34 & -1.53 & -1.50 & 0.004 & -1.52 & 1.34 \\
\hline $3 \times 5$ & $6.33 * *$ & -6.40 & -0.05 & 2.57 & 6.33 & $45.24 *$ & $0.70 *$ & 8.41 & $-8.75^{*}$ & 0.50 & -1.06 & 3.50 \\
\hline $4 \times 5$ & $7.33 * *$ & -3.95 & 0.27 & -8.97 & -6.77 & -27.85 & -0.55 & -11.93 & -2.06 & -2.77 & 0.35 & 2.41 \\
\hline
\end{tabular}

${ }^{*}$ and ${ }^{* *}$ significant difference at level 0.05 and 0.01 respectively. 


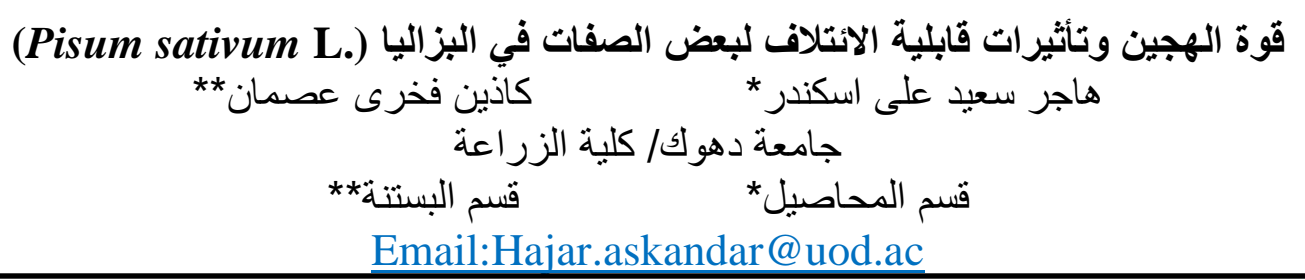

\section{الخلاصة}

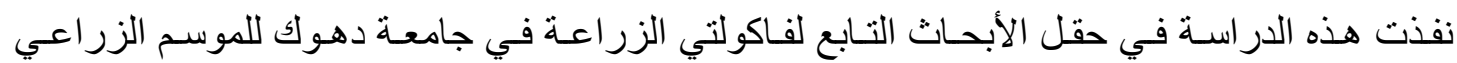

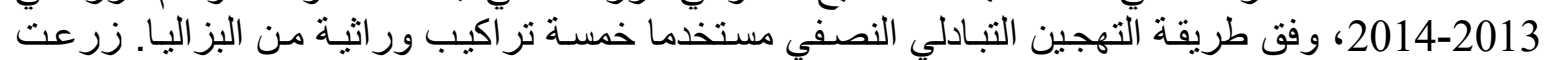

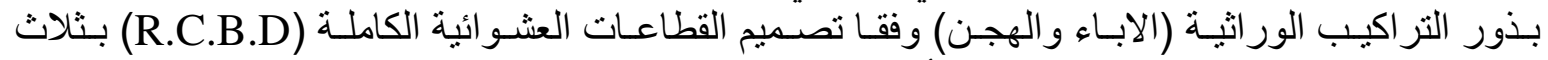

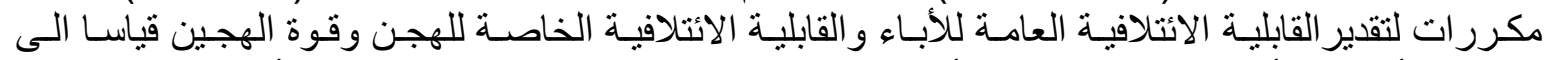

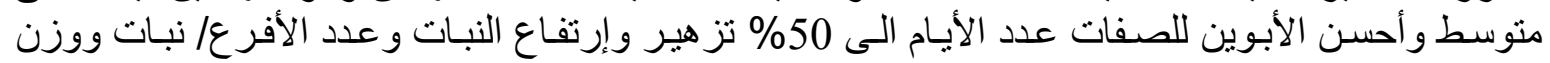

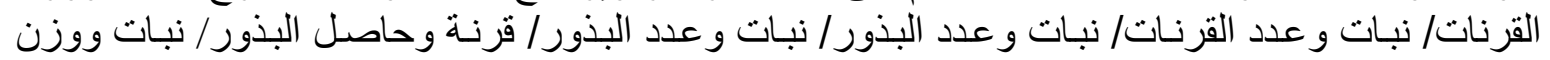

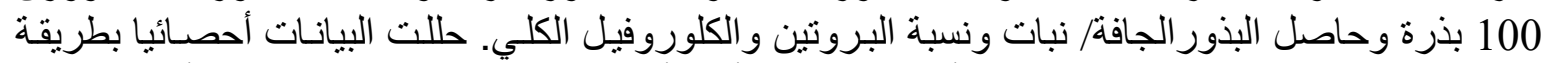
Griffing (1956b)

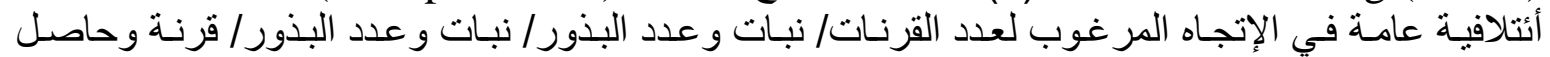

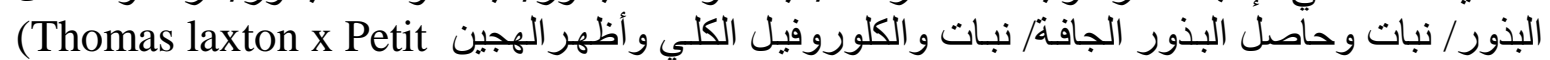

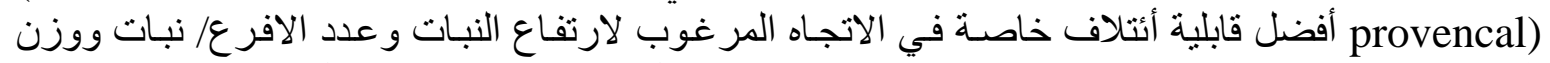

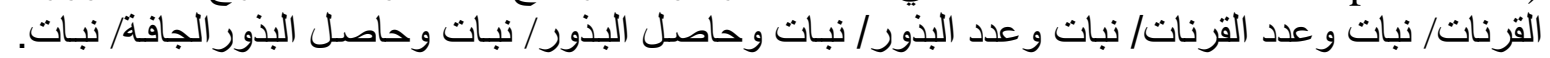

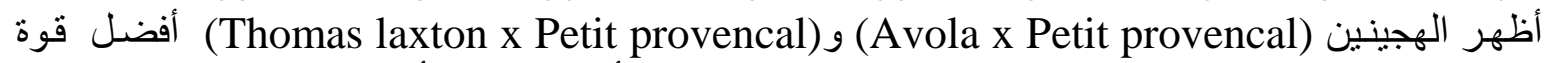

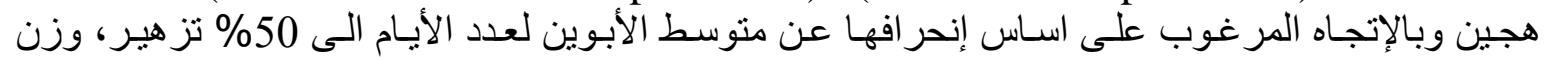

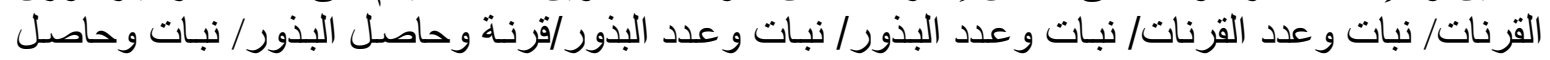

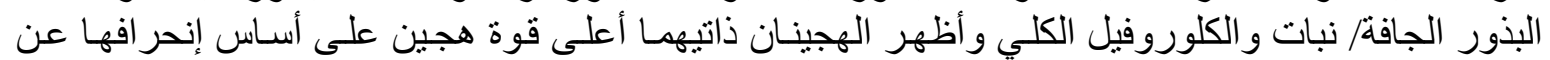

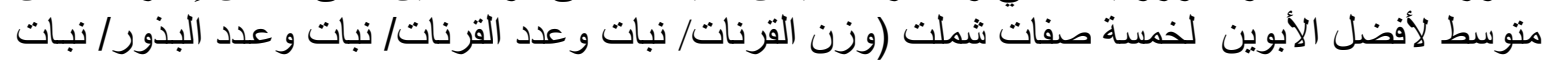

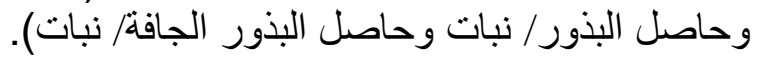

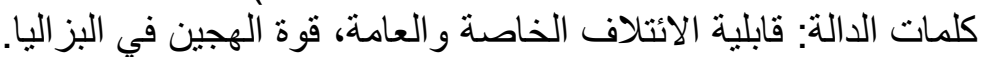

\section{REFERENCES}

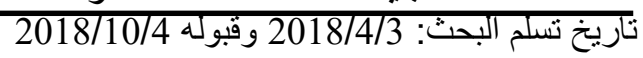

Al-Hamdany, H. Sh. Y. (2014). Estimation of heterosis, combining ability, gene action, genotypic and phenotypic correlation in pea (pisum sativum L.). Jordan J. of Agri. Sci., vol. 10, No. 2.

Bastianelli, D., F. Grosjean, C. Peyronnet, M. Duparque, and J. M. Regnier (1998) .Feeding value of pea (Pisum sativum L.) Chemical composition of different categories of pea. Anim. Sci., 67(3): 609-620.

Bisht, B. and Y. V. Singh (2011). Combining ability for yield and yield contributing characters in pea (Pisum Sativum L.). Vegetable sci., 38(1): 17-21.

Borah, K. H. (2009) Studies on combining ability and heterosis in field pea (Pisum sativum L.). Legume Res. 32(4): 255-259.

Ceyhan, E. and M. A. Avci (2005). Combining ability and heterosis for grain yield and some yield components in pea (Pisum Sativum L.). Pakistan J. of Biological Sci., 8(10): 1447-1452.

Ceyhan, E. M. A. Avci, and S. Karada (2008). Line $\times$ tester analysis in pea (Pisum sativum L.): Identification of superior parents for seed yield and its components. Afr. J. Biotechnol, 7(16): 2810-2817

Chen, Z.J. (2010). Molecular mechanisms of polyploidy and hybrid vigor. Trends Plant Sci. 15: 57-71. 
Dagla, M. C., S. B. L. Srivastav, N. Kumar and H. P. Mella. (2013). An assessment of combining ability and heteroses for yield attributs in field pea (Pisum sativum L.). J. of Progressive Agri., vol.4, No.1.

Dixit, G. P. (2003). Combining ability analysis in Field pea. Indian J. Pulses Res. $16(1): 20-21$.

Esposito, M. A., I. Gatti, V. P. Crarero, F. S. L. Anido and E. C. Cointry (2013). Combining ability and heterotic groups in Pisum sativum L. A.J.C.S., 7(11).1634-1641.

Griffing, B. (1956b). Concept of general and specific combining ability in relation to diallel crossing system. Aust. J. Biol. Sci. 9:463-493.

Gritton, E. T. (1975). Heterosis and combining ability in a diallel cross in peas. Crop Sci. 9:463-493.

Inamullah, H. Ahmed, F. Muhammad, Sirajuddin, G. Hassan and R. Gul (2006). Evaluation of heterotic and heterobeltiotic potential of wheat genotype for improved yield. Pakistan Journal of Botany. 38(4), 1159-1168.

Kosev, V. (2014). Breeding and genetic assessment of some quantitative traits in crosses forage pea (pisum sativum L.). J. of Genetic, 4, 22-29.

Kumar, J. C. and S. S. Bal (1995). Inheritance of economic traits in garden pea (Pisium sativum L.). Haryana J. Hort. Sci. 24(3-4):251-255.

Lejeune-Henaut, I., G. Fouilloux, M. J. Ambrose, V. Dumoulin and G. Eteve (1992). Analysis of a 5- parent half diallel in dried pea (Pisum Sativum L) 1. Seed yield heterosis. Agronomie 12,545-550.

McPhee, K. (2003). Dry pea production and breeding: A minireview .Journal of Food Agriculture And Environment 1:64-69.

Mitu, H. M. K., A. K. M. A. Islam, J. U. Ahmed and M. A. K. Mian. (2004). Combining ability for yield related characters in Pea (Pisum sativum L). J. Asiat. Soc. Bangladesh, Sci., 30(2): 55-62

Nassef, D. M. T. and M. A. El - Rawy (2013) analysis of gene effects controlling some traits in garden pea (Pisum Sativum L.). Aust. J. of basic and applied Sci., 7(1):537-542.

Pallavi, Y. V. Singh, A. Singh, K. K. Pandy and A. K. Awsthi (2013). Genetic variability, estimation for various characters in pea (Pisum Sativum L.) for mollisol of uttarakhand. Inter. J. of plant, Animal and Environmental Sci., 3(4):10-13.

Patil, D. S., N. S. Parade, C. P. Gharge and K. P. Singh (2011). Heterosis for yield and it's contributing traits in table pea (pisum sativum). The Asian J. of Horticulture, 6(1): 132-134.

Pulse Canada (2010). http://www.pulsecanada.com/

Rai, G. and A. Mishra (2013). Heterosis inbreeding depression and its traits in field pea. Plant Archives, 13(1):405-408.

Richy, F. D. (1946). Hybrid vigor and corn breeding. Agron. Vol. 5, No. 38: 833841.

Samatadze, T. E., D. A. Zelenina, N. G. Shostak, A. A. Volkov, K. V. Popov, O. V. Rachinskaya, A. Y. Borisov, I. A. Tihonovich., A. V. Zelenin and O. V. Muravenko (2008). Comparative genome analysis in pea (Pisum sativum 
L.) Varieties and Lines with chromosomal and molecular markers. Russian J. of Genetics, 44:1424-1430.

Sarawat, P., F. L. Stoddard, D. R. Marshall and S. M. Ali (1994).heterosis for yield and related characters in pea. Euphytica 80:39- 48 .

Sato, S., S. Isobe and S. Tabata (2010). Structural analyses of the genomes in legumes. Current Opinion in Plant Biology, 13:146-152

Sharma, T. R. (1999). Combining ability and heterosis in garden pea (Pisum sativum var. arvense) in the cold desert Himalyan region. Indian J. Agric. Sci. 69:386-358.

Sharma, V. K. and L. Bora (2013). Studies on genetic variability and heterosis in vegetable pea (Pisum sativum L.) under high hills condition of Uttarakhand, Index. Afr. J. Agri. Res., 8(18):1891-1895.

Smykal, P., G. Aubert, J. Bustin, C. Coyne, N. Ellis, A. Flavell, and T. Warkentin (2012). Pea (Pisum sativum L.) in the genomics era .Agronomy, 2(2): 74115.

Sprague, G. F. and L. A. Tatum (1942). General vs specific combining ability in single crosses of cron. J. Am. Soc. Agron. 34:923-932.

Srivastava, P. L., U. S. Joshi and H. G. Singh (1986). Combining ability and heterosis in pea. Crop Improv. 13:20-23.

Tawfiq, Sh. I. and S. M. S. Abdulla (2014). Genetic analysis for seven pea varieties and their half diallel hybrids for forage and seed yield. J. of Zankoy Sulaimani-part A, spcial Issue, vol. 16.

Yoshida H., Y. Tomiyama, M. Tanaka and Y. Mizushina. (2007). Distribution of fatty acids in triacylglycerols and phospholipids from peas (Pisum sativum L.). Journal of the Science of Food and Agriculture 87:2709-2714. 
Mesopotamia J. of Agric.

Vol. (46) No. (4) 2018
ISSN: 2224 - 9796 (Online)

ISSN: 1815 - 316 X (Print)

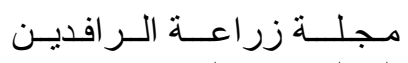

المجلد (46) العدد (4) 2018 